\title{
排気と真空ポンプ
}

湯山 純平*1 · 末次 祐介*2

\section{Evacuation and Vacuum Pumps}

\author{
Junpei YUYAMA*1 and Yusuke SUETSUGU*2
}

*1ULVAC Japan, Ltd., 2500 Hagisono, Chigasaki-shi, 253-8543 Kanagawa, Japan

*2High Energy Accelerator Resarch Organization, 1-1 Oho, Tsukuba-shi, 305-0801 Ibaraki, Japan

(Received February 22, 2013, Accepted April 8, 2013)

\begin{abstract}
Presented here are the fundamental concepts of evacuation process and the key features of various vacuum pumps. Several essential terms, including evacuation time constant, pumping speed and conductance, are introduced to help the understanding of evacuation mechanism and to enable the design of vacuum systems. The vacuum pumps are systematically classified with their operating principles, structures and characteristics. It will help readers to select the proper vacuum pumps and to realize the reasonable vacuum system in different situations.
\end{abstract}

\section{1. はじめに}

真空とは「大気圧よりも低い状態」を表す。すべての真空 作業は，当然のことながら「真空」を作り出すことから始ま る.「排気」とは，文字通り，ある容器（真空を扱うので真 空容器とも呼ばれる）内にある気体を真空ポンプを使って容 器から排出し, 真空を作り出す過程である. 身近な電気掃除 機（これも真空ポンプの一種, 英語では Vacuum cleaner) を想像すると，「排気」には真空ポンプで容器の中の気体を 積極的に吸い出す過程のような印象があるが，実際はそうで はない，また，容器内の空間にある気体分子を吐き出してい けばいくらでも低い圧力が得られる，という単純なものでも ない. 自分が必要とする真空（圧力）を得るためには, 排気 の過程について十分理解し, 場合に応じて適切な真空ポンプ を選択する必要がある。ここでは, 容器を排気する際に必要 な基礎知識々, 各種真空ポンプの特性等について解説する. 多少数式も出てくるが, 現象をより明確に表すために有用で あり, また, 真空を作る作業には基本となるものばかりなの で, 意味を理解して頭の隅にでも留めて頂きたい。 また, 理 解の程度を確認するために, ぜひ問題にも挑戦して頂きたい.

\section{2. 排気の式}

まずは，「排気」とは実際どういう過程かを考える，今， 図 1 のように, 体積 $V$ の容器に気体分子が密度 $n$ で満たさ れているとする. 容器内の気体分子数 $N$ は $n V$ である.こ の容器に, 仮想的に, ある短い時間 $\Delta t$ 毎に体積 $v$ の空「箱」 が取り付けられるとする（ $v$ はよりも十分小さいとす る). 現実では, この「箱」は真空ポンプに相当する.する と, この箱には容器側から気体分子が勝手に飛び込み, $v n$ の気体分子で満たされる. そして時間 $\Delta t$ 後, この「箱」を 取り去る，そうすれば，容器の気体分子数はその分減る，つ まり排気されることになる，これを式で表すと，時間 $\Delta t$ の 間に变化する容器内分子数 $\Delta N$ は, 容器の体積 $V$ は通常一

*1 株式会社アルバック (一253-8543 神奈川県茅ケ崎市萩園2500)

*2 高エネルギー加速器研究機構（干305-0801 茨城県つくば市大 穂 1-1)

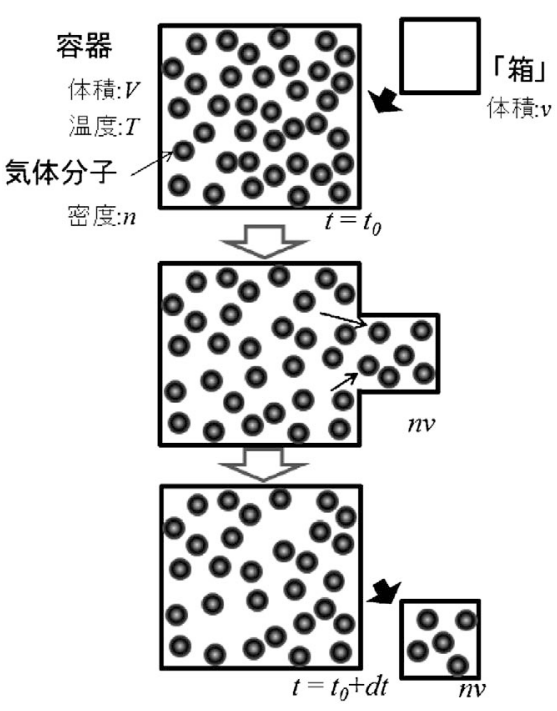

図 1 排気過程の模式図.

定なので

$$
\frac{\Delta N}{\Delta t}=V \frac{\Delta n}{\Delta t}=-\frac{v}{\Delta t} n
$$

となる.つまり, 容器内の気体分子数の減少は, その時の気 体分子数 $n$ と $\Delta t$ 毎に取り付ける「箱」の体積 $v$ に比例する ことになる．これが排気過程の基礎となる概念である。いわ ゆる容積移送式真空ポンプでは正にこのイメージである. 特 定の表面への吸着を利用する溜込み式真空ポンプでは，そ の表面が「箱」の入口と見なすことができる. 各種真空ポン プについては 9. 以降で解説する. ここで, 式(1)から,

$$
V \frac{\Delta n}{\Delta t}=-S n, \frac{v}{\Delta t} \equiv S
$$

とS を定義する。この $S$ は単位時間に持ち去られる体積を 表し,「排気速度」と呼ばれる.排気速度は真空ポンプの性 能を表す重要な指標の一つである. SI 単位系では $\left[\mathrm{m}^{3} \mathrm{~s}^{-1}\right]$ の単位を持ち, 慣例的には $\left[\mathrm{Ls}^{-1}\right]$ もよく用いられる. 大 
気圧付近で使用される真空ポンプでは $\left[\mathrm{L} \mathrm{min}^{-1}\right]$ で表示さ れる場合も多い。ちなみに，「排気速度」というものに最初 にイメージする単位は［個 $\mathrm{s}^{-1}$ ] かもしれない（“個”は分 子の個数). しかし, 式(2)のように $\left[\mathrm{m}^{3} \mathrm{~s}^{-1}\right]$ の単位で定義 すると，排気速度は分子密度（つまりは圧力）に依らないの で, 例えば真空ポンプの性能を表すのに好都合なものとなる.

さて, 上で述べた様な排気のモデルでは, 密度の変化は滑 らかではない $(\Delta t$ 毎にガタガタと変化する)。しかし, 通常 の時間スケールではその変化は時間的に十分滑らかに進むと 考えてよい.そこで, 密度は時間的な平均を取って滑らかに 変化するとして，時間 $\Delta t$ をどんどん短くし $\Delta t \rightarrow 0$ の極限を とると（数学の常套手段であるが）, 式(2)から次の微分方 程式が導かれる。

$$
V=\frac{d n}{d t}=-S n
$$

この式は, 正に容器内の気体分子の排気過程を表すものであ るが，実際には分子密度 $n$ を直接測定することは困難なの で, 測定可能な圧力 $p$ で表現した方が実用上都合よく, 実際 的である. 本講座の「気体分子運動論の基礎」でも出てくる 理想気体の状態方程式

$$
p=n k T
$$

( $k$ : ボルツマン定数, $T$ : 温度) を使って式(3)を書き直す と, 温度を一定として

$$
V \frac{d p}{d t}=-S p
$$

を得る [問：これを示せ]. この式は「排気の式」と呼ばれ， 排気過程を考える上で非常に重要な式である. 排気の式(5) を, $t=0$ で圧力 $p=p_{0}$ (定数) という初期条件の下に圧力 $p$ について解くと,

$$
\begin{aligned}
& p=p_{0} \exp \left(-\frac{S}{V} t\right)=p_{0} \exp \left(-\frac{t}{\tau}\right), \\
& \tau \equiv \frac{V}{S}
\end{aligned}
$$

が得られる [問 : これを示せ].すなわち, 圧力は時間とも に指数関数的に減少する. 減少の程度を表す $\tau \equiv V / S$ は「排 気の時定数」と呼ばれ, 圧力が初期圧力の $1 / \mathrm{e}$ (約 $1 / 3)$ に

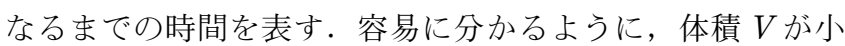
さいほど，また排気速度 $S$ が大きいほど時定数は小さい (排気が速い). また, 容器の体積が分かっていれば, 測定し た圧力を対数目盛で, 排気時間を線形目盛で圧力変化をグラ フ化した時に，その圧力変化の傾きから真空ポンプの排気速 度を推定することができる [問題 1].

この節で述べた事は，非常に理想的な場合である．実際に は, 圧力は単調に指数関数的に下がることはない。それは, 上記の議論では容器壁等に吸着していた気体分子の放出や, 容器外部からのリークが含まれていないからである。この点 については後でもう一度触れる。
問題 1 図 2 は, 体積 $0.8 \mathrm{~m}^{3}$ の容器を真空ポンプで排気始めた直後 の圧力変化の様子である. 縦軸は対数目盛の圧力, 横軸は線形目盛 の排気時間である. 排気開始約 10 分後のデータからこの真空ポンプ の排気速度を推定してみよう。

ヒント：式(6)の両辺の対数をとると,

$$
\log p=\log p_{0}-\frac{t}{\tau} \log e \quad \therefore \frac{\Delta(\log p)}{\Delta t}=-\frac{\log e}{\tau}
$$

\section{3. 流量とコンダクタンス}

式 (5)の $-d(p V) / d t$ は，単位時間に容器から流れ出す量 を表しており，気体の「流量」（あるいは「体積流量」）と呼 ばれる. 圧力 $p$ と体積 $V$ の積で表されているので，「 $p V$ 值」 で表した流量とも言う。式(4)からわかるように $p V$ 值を $k T$ で割れば分子数 $N$ が得られる，今，図 3 のように，二つの 容器 1 と 2 が配管で連結されているとして，その間の気体 の流れを考えてみる.それぞれの容器内の圧力を $p_{1}, p_{2}$ と する。まず, 図左側の容器 1 だけに注目すると, 容器 1 か ら流れ出す流量 $Q_{1}$ は, 容器の排気過程と考えて, 式(5)と 同じく，

$$
Q_{1}=-V_{1} \frac{d p_{1}}{d t}=C_{1} p_{1}
$$

と書くことができる．ここで $C_{1}$ は定数である，同様に，容 器 2 から流れ出す流量 $Q_{2}$ は,

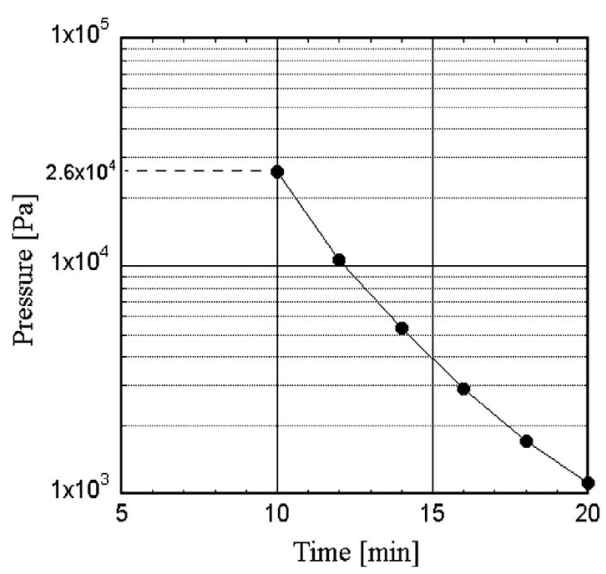

図 2 実際の排気曲線の例。

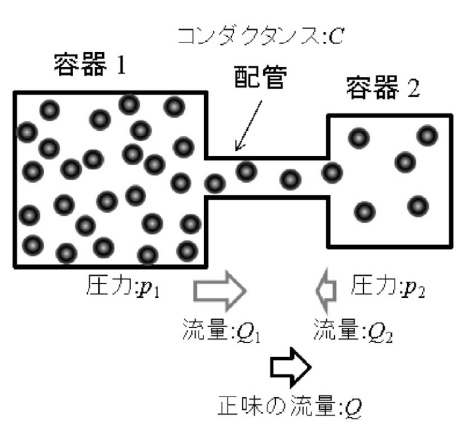

図 3 配管で接続された二つの容器間の気体の流れ. 


$$
Q_{2}=C_{2} p_{2}
$$

となる $\left(C_{2}\right.$ は定数)，したがって, 容器 1 から容器 2 に流れ る正味の流量 $Q$ は

$$
Q=Q_{1}-Q_{2}=C_{1} p_{1}-C_{2} p_{2}
$$

となる.もし容器 1 と 2 の压力が等しい場合 $\left(p_{1}=p_{2}=p\right)$, 当然正味の流れは無いので,

$$
Q=C_{1} p-C_{2} p=\left(C_{1}-C_{2}\right) p=0
$$

である. 圧力 $p$ は任意の值をとれるので, 結局 $C_{1}=C_{2}$ とな り，正味の流量 $Q$ は次のように表せる.

$$
Q=C\left(p_{1}-p_{2}\right)
$$

つまり, 正味の流量は繋がれた二つの容器の圧力差に比例す る.この比例定数 $C$ は, 配管の「コンダクタンス」と呼ば れる.コンダクタンスとは気体の流れやすさの指標となるも ので, 同じ圧力差では $C$ が大きいほど流量が大きくなる. コンダクタンスは, 配管等の太さ, 長さ, 気体の種類, 温度 に依存する，また後述するように圧力によって変わる場合も ある、コンダクタンスの単位は SI 単位系で $\left[\mathrm{m}^{3} \mathrm{~s}^{-1}\right]$ とな り，排気速度と同じ単位である。また，式(7)，(8)から， コンダクタンスはつながれた二つの容器のどちら側から見て も同じである。つまり，配管のコンダクタンスは気体の流れ の向きに依らないこともわかる.

さて，1.で述べた排気過程では, 容器に直接排気速度 $S$ のポンプを取りけた「理想的な」場合を考えた。しかし実際 には，容器と真空ポンプの間にはなんらかの配管やバルブ等 が挟まる場合がほとんどである。そこで今度は，図 3 にお いて, 容器 2 の所に排気速度 $S$ の真空ポンプが繋がれてい るとしよう。つまり, 容器 1 にコンダクタンス $C$ の配管を 通して排気速度 $S$ の真空ポンプが繋がれていることにな る. 圧力 $p_{2}$ はポンプ入口の圧力とみなせる. この時, 容器 1 から流れ出す流量 $Q$ は配管部分, および真空ポンプ部分 に注目して,

$$
\begin{aligned}
& Q=C\left(p_{1}-p_{2}\right) \\
& Q=S p_{2}
\end{aligned}
$$

となる．これら二つの式を組み合わせて $Q$ を $p_{1}$ で表すと，

$$
Q=\frac{S C}{S+C} p_{1}=S_{\mathrm{eff}} p_{1}, S_{\mathrm{sff}} \equiv \frac{S C}{S+C}
$$

と書くことができる [問：これを示せ]．この $S_{\mathrm{eff}}$ は，配管 の影響を含めた「実効（あるいは有効）排気速度」と呼ばれ る．実際の真空装置で排気システムを考える場合には，この $S_{\mathrm{eff}}$ の評価が重要なポイントとなる．いくら使用する真空ポ ンプの排気速度 $S$ を大きくしても, 配管等のコンダクタン ス $C$ が小さければ，実際の排気速度は結局そのコンダクタ ンスで制限されることになるからである[問：これを示せ $].$
問題 2 図 3 の排気システムにおいて, 真空ポンプ (容器 2) の排 気速度 $S$ が $0.3 \mathrm{~m}^{3} \mathrm{~s}^{-1}$, 繋いだ配管のコンダクタンスが $0.05 \mathrm{~m}^{3} \mathrm{~s}^{-1}$ であった場合, 実効排気速度 $S_{\mathrm{eff}}$ はどうなるか評価してみよう。

\section{4. 配管の組み合わせ}

ここでは, 容器に配管等が複数接続されている場合を考え る. 図 4(a) は, 容器に二本の配管が「直列」に接続されて いる場合である。これは，バルブ等が含まれる場合に相当す る. 一方図 4(b) は，二本の配管が「並列」に接続されてい る場合である. 排気初期の排気効率を上げるために用いられ ることがある。これらの組み合わせの場合に，配管全体とし てのコンダクタンス（「合成コンダクタンス」と呼ぶ）はど うなるだろうか。

まず，図 4(a)の直列接続の場合，真空ポンプまでの配管 全体を流れる流量は同じであるから，流量に関して下記の式 を得る。

$$
\begin{aligned}
& Q=C_{1}\left(p_{1}-p^{\prime}\right) \\
& Q=C_{2}\left(p^{\prime}-p_{2}\right)
\end{aligned}
$$

ここで $p^{\prime}$ は配管 1 と 2 の間の圧力である.式(14)から $p^{\prime} を$ 消去すると，合成コンダクタンス $C$ は

$$
\begin{aligned}
& Q=\frac{C_{1} C_{2}}{C_{1} C_{2}}\left(p_{1}-p_{2}\right)=C\left(p_{1}-p_{2}\right) \\
& \therefore C \equiv \frac{C_{1} C_{2}}{C_{1}+C_{2}}
\end{aligned}
$$

である [問：これを示せ］. 式(15)の下の式を書き直すと，

$$
\frac{1}{C}=\frac{1}{C_{1}}+\frac{1}{C_{2}}
$$

となる．合成コンダクタンスの逆数は，それぞれのコンダク タンスの逆数の和となる。つまり，コンダクタンス（流れ易

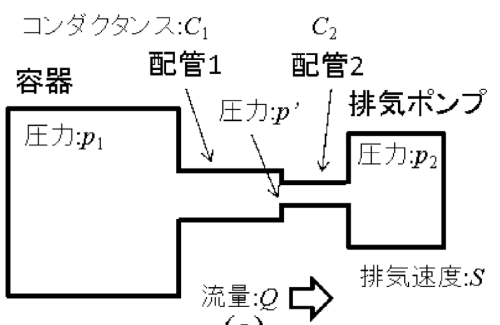

(a)

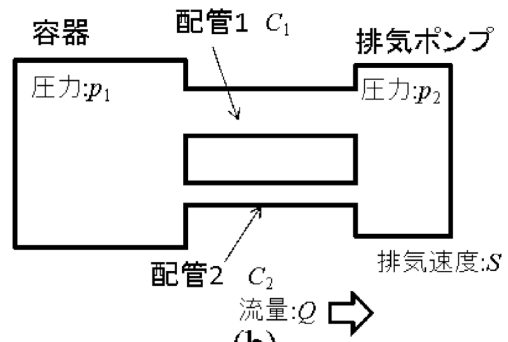

(b)

図 4 典型的な二種類の配管. 
さ）の逆数は「抵抗」とみなすことができるので, 配管が直 列に繋がれている場合は，その抵抗の和，と考えることがで きる. 一方のコンダクタンスが小さいと, 合成コンダクタン スは小さい方に引きずられて小さくなる.

圧力差, 流量とコンダクタンスの関係は, しばしば電気回 路に例えられる，すなわち，圧力差を電圧，流量を電流と考 えれば，電気回路におけるオームの法則と同様に扱うことが できる. 電気抵抗はコンダクタンスの逆数なので, 式 (14) は直列回路のオームの法則と同等のものとなる.つまり, 式 (16) は直列回路全体の電気抵抗がそれぞれの電気抵抗の単 純な和となることに相当する。

一方, 図 4(b)のように配管が並列に繋がっている場合, それぞれの配管の流量を $Q_{1}, Q_{2}$, 全体の流量を $Q$ とすれば,

$$
\begin{aligned}
& Q_{1}=C_{1}\left(p_{1}-p_{2}\right) \\
& Q_{2}=C_{2}\left(p_{1}-p_{2}\right) \\
& Q=Q_{1}+Q_{2}
\end{aligned}
$$

これらの式から，

$$
\begin{aligned}
& Q=\left(C_{1}+C_{2}\right)\left(p_{1}-p_{2}\right)=C\left(p_{1}-p_{2}\right) \\
& \therefore C \equiv C_{1}+C_{2}
\end{aligned}
$$

すなわち，合成コンダクタンスはそれぞれのコンダクタンス の和，となる。原理的には，配管を増やした分だ合成コン ダクタンスは大きくなる，再び電気回路に例えると，式 (18) は, 並列回路全体の電気抵抗の逆数がそれぞれの電気 抵抗の逆数の和になることに相当する.

ここでは，二本の配管について考察したが，より多くの配 管が並列・直列に慗がれている場合でも，配置を分解して同 様に考えることができる。

問題 3 図 4 において, 配管のコンダクタンスが, $C_{1}=0.1 \mathrm{~m}^{3} \mathrm{~s}^{-1}$, $C_{2}=0.01 \mathrm{~m}^{3} \mathrm{~s}^{-1}$ の時, 直列接続 (a) と並列接続 (b)の場合のコンダ クタンスを求めてみよう.

\section{5. 気体の流れとコンダクタンス}

コンダクタンスについてもう少し詳しく見る前に，配管等 の中の気体の流れを，その「希薄さ」に関して分類しておく.

気体の平均自由行程（気体分子が他の気体分子と衝突する までに移動する距離の平均） $\lambda$ は, 再び「気体分子運動論の 基礎」から,

$$
\lambda=\frac{k T}{\sqrt{2} \pi \sigma^{2} p}
$$

と表される，ここで $\sigma$ は気体分子の直径である．ちなみに， $20^{\circ} \mathrm{C}$ 空気では $\lambda=6.6 \mathrm{~Pa} \mathrm{~mm} / p$ である（例えば， $p=2 \mathrm{~Pa}$ の時は $\lambda=3.3 \mathrm{~mm}$ となる). $\lambda$ は圧力に反比例し, 圧力が低 いほど $\lambda$ は長くなる。もし， $\lambda$ が配管の代表的な寸法（例え ば丸管の場合は直径）よりも十分小さい場合，気体分子の衝 突は分子同士の衝突が主となり，流れは気体の粘性で支配さ れる（図 5(a)).この領域の気体の流れを「粘性流」という. 一方, もし， $\lambda$ が配管の代表的寸法より十分長い場合, 気体 は「希薄」となり，気体分子の衝突は配管の壁との衝突が主

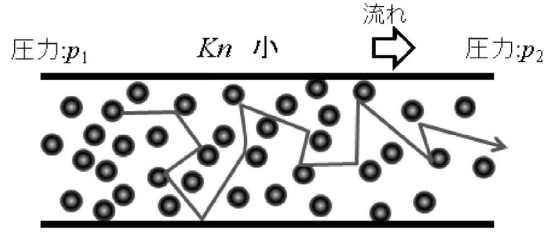

(a)

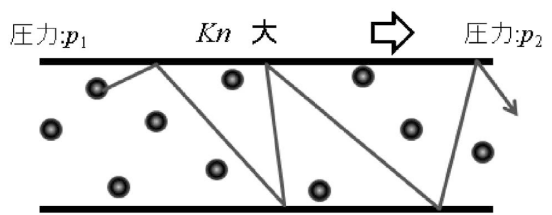

(b)

図 5 (a)粘性流領域と (b) 分子流領域での気体の流れの模式 図.

となる（図 5(b))．この領域の流れを「分子流」という。ち なみに，その間の領域は「中間流」と呼ばれる.

流体力学では，その流体の特性を示すために無次元数がよ く用いられるが，この「希薄さ」の指標は，クヌーセン (Knudsen) 数 $K_{\mathrm{n}}$ である. すなわち, 配管の代表的長さを $d$ として

$$
K_{\mathrm{n}} \equiv \frac{\lambda}{d}=\frac{k T}{\sqrt{2} \pi \sigma^{2} p d}
$$

で定義される．ここで， $K_{\mathrm{n}}$ が圧力と配管寸法の積， $p d ， に$ 依存することに注目すべきである.つまり同じ圧力でも, 配 管の寸法によって流れの領域が異なる. 真空工学において は, 各流れの領域は $K_{\mathrm{n}}$ 数によって下記のように分類される.

$$
\begin{aligned}
& \text { 分子流 : } 0.3<K_{\mathrm{n}} \\
& \text { 中間流 : } 0.01<K_{\mathrm{n}}<0.3 \\
& \text { 粘性流 }: K_{\mathrm{n}}<0.01
\end{aligned}
$$

例えば， $20^{\circ} \mathrm{C}$ 空気の場合， $K_{\mathrm{n}}$ は

$$
K_{\mathrm{n}}=\frac{6.6}{p[\mathrm{~Pa}] d[\mathrm{~mm}]}
$$

で与えられる．排気過程は，粘性流から始まり，中間流を経 て分子流に至る。配管と容器の大きさに依存するが，通常の 真空装置では，拈よそ $1 \mathrm{~Pa}$ 以下であれば分子流を取り扱う ことになる。

問題 $420^{\circ} \mathrm{C}$ の空気で, 配管が $d=20 \mathrm{~mm}$ の時, $K_{\mathrm{n}}=0.3$ となる （分子流領域と見なせる）圧力 $p$ はどのくらいだろう.

さて，配管のコンダクタンスは，気体の流れ具合を示すも のであるから，その流れが上に述べたどの領域にあるか，で 当然变わってくる．ここでの導出は割愛するが，半径 $a$ の円 断面を持つ長い配管の場合, 粘性流と分子流でのコンダクタ ンスはそれぞれ下記のように与えられる。

$$
\left.C=\frac{\pi a^{4} \bar{p}}{8 \mu L} （ \text { 粘性流領域 }\right)
$$




$$
C=\frac{2 \pi a^{3} \bar{v}}{3 L}(\text { 分子流領域 })
$$

ここで， $\bar{p}$ は配管の平均圧力（配管両側の圧力の平均）, $\mu$ は粘性係数, $L$ は配管の長さ, $\bar{v}$ は気体分子の平均速度 $\bar{v}=$ $\sqrt{8 k T / \pi m}$ ( $m$ は気体分子の質量 $)$ である。粘性流領域での コンダクタンスは, 配管内の圧力に依存し，また，配管の半 径の 4 乗に比例する。 一方，分子流領域でのコンダクタン スは，圧力に依存せず，また，配管の半径の 3 乗に比例す る.したがって，排気を考える場合，気体の流れがどの領域 にあるかを理解することは非常に重要である．先にも述べた ように，高真空，超高真空を扱う場合，ほとんどの排気過程 は分子流領域にある。しかし，気体を積極的に導入するプロ セス装置では，通常状態で粘性流となる場合もある，中間流 領域のコンダクタンスは簡単には求められないが，分子流領 域と粘性流領域の值を滑らかにつないだものと考えてよい.

\section{6. 理想排気速度}

ここでは，希薄な流れにおいて重要な「理想排気速度」に ついて述べる. 今, 図6のように, 容器に面積 $A$ の穴（真 空ポンプ入口に相当）が開いているとする，分子流領域で は, 「気体分子運動論の基礎」から, 容器壁への入射頻度 $\Gamma_{\mathrm{i}}$ （単位時間に単位面積に衝突する気体分子の数）は

$$
\Gamma_{\mathrm{i}}=\frac{1}{4} n \bar{v}
$$

である．理想的な場合，穴から出て行った気体分子がすべて 排気される. 面積 $A$ の穴から流れ出る流量 $Q$ は， $k T$ を乗 じて $p V$ 值で表すと

$$
Q=\frac{1}{4} A \bar{v} p=S_{0} p, S_{0} \equiv \frac{1}{4} A \bar{v}
$$

で表される [問 : これを示せ］この排気速度 $S_{0}$ は「理想排 気速度」と呼ばれる．実際の排気速度は理想排気速度より大 きくなることは無い。例えば $20^{\circ} \mathrm{C} の$ 空気の場合には $S=A \times$ $117 \mathrm{~m}^{3} \mathrm{~s}^{-1}$ である. 面積 $1 \mathrm{~cm}^{2}$ のオリフィスのコンダクタン スは $11.7 \mathrm{~L} \mathrm{~s}^{-1}$ である [問：これを示せ］：この数值は実際 の排気作業で有用な值であるので記憶しておくと便利である.

式 (25)の排気速度 $S_{0}$ は, 図 3 の容器 1 と 2 が, 厚みの無 い穴（オリフィス）で接続されている時のコンダクタンスと みることもできる，穴を通った分子は必ず隣の容器に入るか
らである・つまり,

$$
Q=C_{0}\left(p_{1}-p_{2}\right), C_{0} \equiv \frac{1}{4} A \bar{v}
$$

である．容器 2 からの流量が無い，すなわち， $p_{2}=0$ とする と, 式(23) と同等となる.

詳しくは述べないが，分子流の場合の配管のコンダクタン スは，この配管入口面（オリフィスと見なせる）のコンダク タンスに，この配管を反対側まで通過できる確率（これを 「通過確率」と呼ぶ）を掛けたものと考えることができる. つまり，配管を気体が流れるという現象は，(1)気体分子が配 管の入り口開口部にはいる，(2)配管に入った気体分子が配管 を移動する，という二つの過程に分けて考えることができ る.この通過確率の考え方は，一般的な配管のコンダクタン スを評価する上で役に立つ

\section{7. 実際に近い排気システム}

排気過程の解説の最後に, 実際の排気システムに近い条件 で排気を考えてみる。図 7 のように，容器が，配管 2 本 （コンダクタンス $C_{1}, C_{2}$ ) を介して真空ポンプ（排気速度 $S$ ) に接続され，排気されるとする。 まず，容器出口での実効排 気速度 $S_{\mathrm{eff}}$ は，これまでの議論から，

$$
\frac{1}{S_{\mathrm{eff}}}=\frac{1}{C_{1}}+\frac{1}{C_{2}}+\frac{1}{S},=\frac{C_{1} C_{2} S}{C_{1} C_{2}+C_{1} S+C_{2} S}
$$

となる [問 : これを示せ $].$

容器の排気の式は，基本的には式(5)であるが，ここで は, 容器内へのガス放出 $\left(Q_{0}\right)$ があるものとする.これは, 容器内壁からの熱的なガス放出であったり, 容器溶接部から の微小リークであったりする.

まず， $Q_{0}$ は定数と仮定する，そうすると，排気の式は

$$
V \frac{d p_{1}}{d t}=-S_{\mathrm{eff}} p_{1}+Q_{0}
$$

となる. $t=0$ での圧力を $p_{0}$ としてこの微分方程式を解くと,

$$
p_{1}=\left(p_{0}-\frac{Q_{0}}{S_{\text {eff }}}\right) \exp \left(-\frac{S_{\text {eff }}}{V} t\right)+\frac{Q_{0}}{S_{\text {eff }}}
$$

を得る [問：これを示せ $]$.この式からわかるように， $Q_{0}$ が 小さければ（つまり， $p_{1} \gg Q_{0} / S_{\mathrm{eff}}$ の時), 圧力は当初指数関 数的に減少する. しかし，十分長い時間排気して圧力が下が

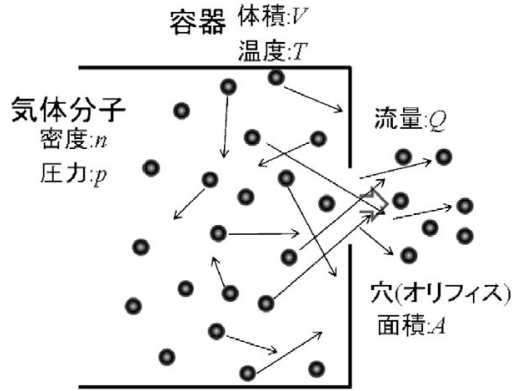

図6 分子流領域にあるオリフィスでの気体の流れの模式図.

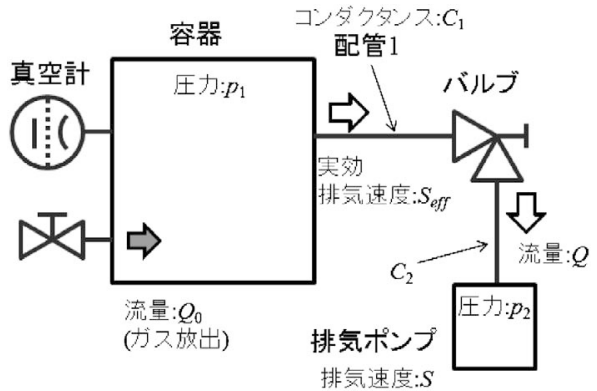

図 7 ガス放出がある場合の排気システム 
ると，ガス放出 $Q_{0}$ が支配的となり，一定圧力

$$
p_{1}=\frac{Q_{0}}{S_{\text {eff }}}
$$

に近づくことになる．式 (29)で表される圧力変化の一例を 図 8 に示す.

容器内のガス放出 $Q_{0}$ が外部からのリーク等である場合は 上の議論でよいが，容器壁からのガス放出であれば，そう単 純ではない，詳しい話は本講座の「真空と表面」の解説に委 ねるとして，ガス放出率 $Q_{0}$ はその時の圧力に依存する，す なわち，排気とともに時間的に変化するからである。ただ し，通常その变化の割合は排気の時定数（式(6)）よりも非 常にゆっくりしている.

これまでに述べたことから，より低い圧力を得るために は, 容器外部から, および容器表面からのガス放出を小さく すること，そして，実効排気速度を大きくすることに尽き

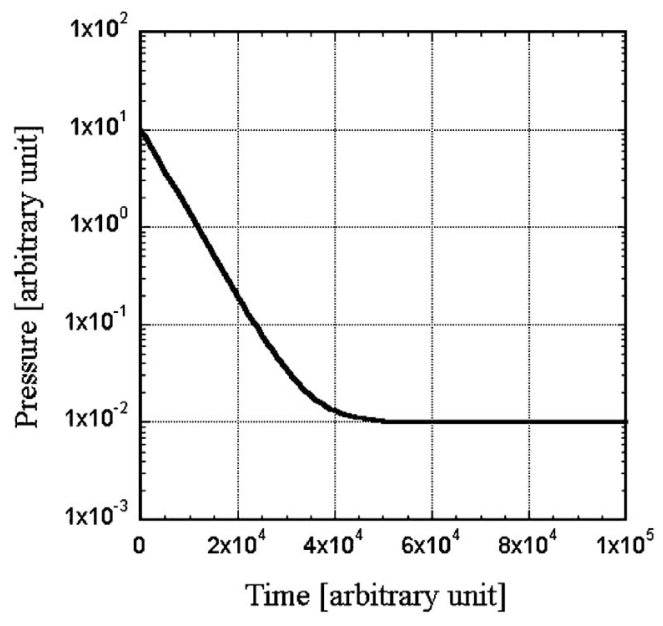

図 8 ガス放出を考慮に入れた排気曲線（計算值）.
る. 前者を達成するためには, 容器の材料, 内表面の洗浄方 法, 加工・溶接方法等を十分吟味して選択する必要がある. また，容器のベーキング等の熱処理も有効である．後者のた めには, 真空ポンプの特徵を良く理解して的確な真空ポンプ を選択しなければならいのはもちろんのこと, 配管系のコン ダクタンスをいかに大きくするかが問題となる.もちろん, 真空ポンプや配管系のガス放出も気体の逆流となり実効的な 排気速度を落とす原因となるので，十分な配慮が必要である.

\section{8. 真空ポンプの動作原理と分類}

ここからは, 真空を作り出す上で主要な役割を果たす真空 ポンプについて述べる. なお, 我が国においては真空ポンプ の分類は JIS（Z-8126-2, 1999）によって表1のように規定 されている11.

真空ポンプに期待される動作は，気体分子を空間から取り 除くことであり，真空容器の空間に存在している気体分子を 「ポンプによって輸送」して除去する方法と, 真空容器内表 面に入射している気体分子のうち特定の表面に入射した気体 分子を「吸着作用によって空間に戻さないようにする」こと で除去する方法とがある。前者に属する機能を持つポンプを 「気体輸送式真空ポンプ」と呼び，後者に属するポンプを 「気体ため込み式真空ポンプ」と呼ぶ.

気体輸送式真空ポンプにおいては, 気体を圧縮し圧力を高 め，より高い圧力領域にまで押し出すことによって（排気し たい）真空容器内の気体分子密度を小さくする．押し出した 気体分子の最終到着圧力は大気圧である。もし，気体を圧縮 して押し出すという気体輸送の働きが停止することがあれ ば，大気圧の気体分子が排気経路を逆にたどって，最も圧力 が低い（気体分子密度が小さい）真空容器まで侵入し, 排気 側に逆止弁が無い場合にはやがて真空容器内は大気圧になる.

これに対して気体ため込み式真空ポンプに抢いては, 真空 容器内に残留している気体分子が特定の吸着可能面に入射し

表 1 真空ポンプの分類（日本規格協会の許可を得て文献 1 より転載).

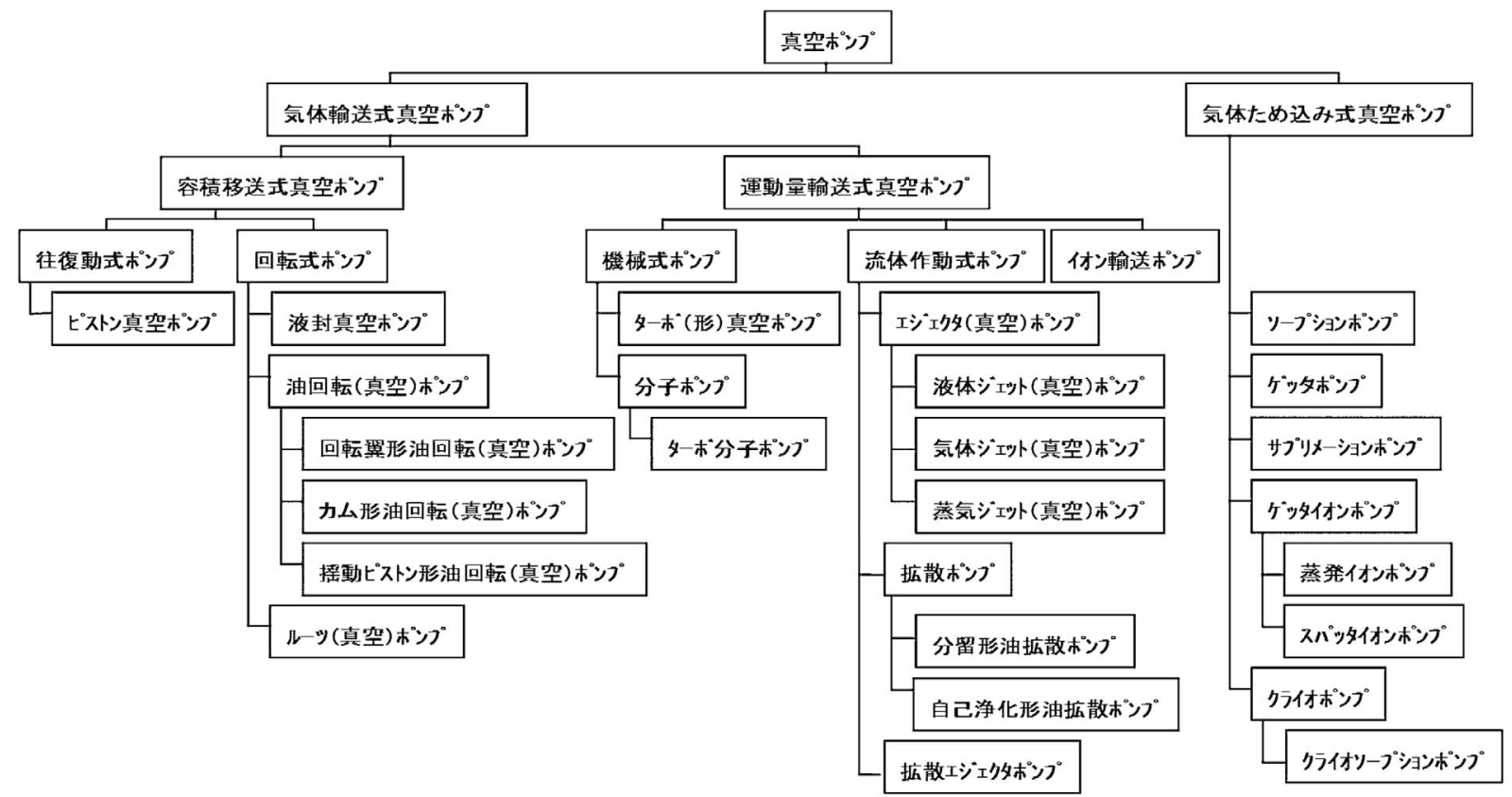


吸着した結果それらは空間に戻ることはない，ということで 排気している.したがって, 吸着可能面が万一その機能を失 い，吸着していた気体分子すべてを放出しても（真空容器内 の気体分子の総数は同じままなので), 排気スタート時点の 圧力に戻るだけである.

\section{9. 真空ポンプの動作特性と性能指標}

真空ポンプには動作できる圧力領域の限界がある.そのた め複数台のポンプを組反合わせて使用することがある. 真空 系を目標の圧力まで排気し，その圧力を保つためのポンプを 「主ポンプ」と呼び, 主ポンプが動作可能な圧力領域をで大 気圧から排気するポンプを「粗引きポンプ」と呼ぶ.また， 主ポンプの背圧をそのポンプが正常に機能できる臨界值以下 に維持するためのポンプを「補助ポンプ」という.ターボ分 子ポンプと油回転ポンプの組反合わせを例にあげれば, ター ボ分子ポンプが主ポンプ, 油回転ポンプが粗引きポンプかつ 補助ポンプである.

各種のポンプに共通する性能指標として, 排気速度があ る。これは気体輸送式, 気体ため込反式のいずれにも共通す る性能指標である. 気体輸送式真空ポンプに固有な指標とし て圧縮比があり, 気体ため込及式に固有な指標には排気容量 がある。

排気速度については, 2.で説明した. ポンプ自身の排気速 度については, カタログや仕様書に記されている. しかし， 実際の真空装置では多くの場合, 排気したい真空容器に配管 やバルブなどが接続され，その先に市販のポンプが接続され る.そこで， 3.で説明したように, 真空容器の排気口におけ る実効排気速度が重要となる。

気体輸送式真空ポンプに固有な性能指標として圧縮比があ る. 気体分子移送の基本動作「気体を圧縮して圧力を高め, より高い圧力領域へ押し出す」際の指標である. 吸気側圧力 $p_{\text {in }}$ と吐出側圧力 $p_{\text {out }}$ を用いて

$$
K=\frac{p_{\text {out }}}{p_{\text {in }}}
$$

と定義される．この際， $p_{\text {out }}$ を徐々に高めていくとやがては ポンプが気体を押し出し切れなくなり, 吐出側から気体輸送 式真空ポンプを通ってポンプ吸気側に気体が逆流することが 起こる.すなわち， $Q_{\text {in } \rightarrow \text { out }}=Q_{\text {out } \rightarrow \text { in }}$ となることが起こる.こ の状態になったときの $p_{\text {out }} / p_{\text {in }}$ を最大圧縮比としている.

気体ため込久式真空ポンプに固有な性能指標に排気容量 （ため込々容量）がある. ポンプを含めた真空容器内部に気 体分子をため込むことが可能になるのは，その空間内に「気 体分子を吸着する表面が存在」していることによる．[単位 面積当たりの最大吸着量 $N_{\text {max }}$ [個 $\mathrm{m}^{-2}$ ] $\times$ [吸着可能な面積 $A_{\mathrm{p}}\left[\mathrm{m}^{2}\right]$ が最大吸着量, すなわち排気容量を与える. 吸着 可能な面積 $A_{\mathrm{p}}$ はクライオポンプのような極低温表面の表面 積, あるいはゲッタ表面（気体分子が吸着する面）の面積で ある. 最大吸着量は気体分子の吸着特性によって変わる. 希 ガスのように化学的に不活性な気体分子の場合, 最大吸着量 は大幅に小さな值となる。一方, 多層吸着 (クライオポンプ) や表面層内部への拡散を伴う吸着 (非蒸発型ゲッタポンプ)
の場合には，最大吸着量は大きな値となる．

\section{0. 真空ポンプ各論}

気体輸送式および気体ため込反式真空ポンプの主な形式に ついて, それらの動作原理, 特徵, 使用上の注意点などを解 説する.

\section{1 気体輸送式真空ポンプ}

\subsection{1 容積移送式真空ポンプ}

10.1.1.1 油回転ポンプ

油回転ポンプ（oil-sealed rotary vacuum pump）は非常に 圧縮比の大きい（ $10^{5}$ 以上）圧縮機の一種である. 真空ポ ンプとしての機能は, 低圧の気体を大気圧以上の圧力に圧縮 し, 大気中に放出することで実現する. 通常は, 真空容器を 大気圧から $1 \mathrm{~Pa}$ 程度の圧力まで粗引きをする, 主ポンプと して動作圧力を保つ, あるいはターボ分子ポンプ等の主ポン プの補助ポンプとして働くなどの目的で使用される。油回転 ポンプの形式としては 3 種類ある. 回転翼形 (ゲーテ形), カム形 (センコ形), 摇動ピストン形 (キニー形) である. [JIS Z-8126-2]

図 9 に，回転翼形油回転ポンプの概略を示す 2 . シリンダ 内にはロータがあり，ロータに設けられた溝には翼が取り付 けられている. 翼はばねの力で常にシリンダ内面に押しつけ られて回転する. シリンダ内の空間は，この回転翼とロータ によって三つに区画される3（図10(a))。図中，左上部空間 Cではロータの回転（図では右まわり）につれて容積が減少 し，気体を大気圧まで圧縮して外部に押し出す．中央下部の 大きな空間 B では気体が移送され，右上部空間 A では容積 の増加につれて気体が吸引される。このシリンダ部全体が油 中に浸されて, 外気の侵入を防いでいる. シリンダ内に入っ た油は, シリンダ内面とロータ・回転翼との摺動部分での潤 滑と気密保持に役立っている. さらに, 到達圧力近くの低い 圧力での排気に重要な役割を果たしている.すなおち, 大気 圧まで压縮された吸気気体の体積が圧縮空間の死容積（機械 的に圧縮できない残容積）よりも小さくなると, 大気圧以上

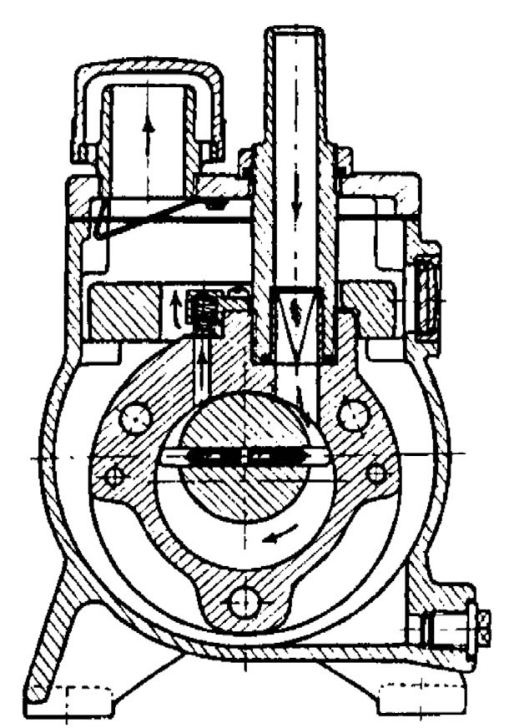

図 9 回転翼形油回転ポンプの概略構造（日本機械学会の許可 を得て文献 2 より転載). 
に圧縮することができず排出が不可能になる，そこで，油に よって死容積を埋め, 気体を泡として取り込んでシリンダ外 に排出する.

カム形油回転ポンプ (図10(b)), 摇動ピストン形油回転 ポンプ (図10(c)) でも，回転翼形と同様にシリンダ内のロー タの動きに伴う区画された容積の変化により排気作用が行わ れる。

\subsubsection{2 メカニカルブースタポンプ}

油回転ポンプの到達圧力近くでの能力低下を補う目的で, 吸気口側に取り付ける機械式ポンプをメカニカルブースタポ ンプという. 図11のように，二葉のまゆ形断面のロータが互 いに逆方向へ等速で回転して吸入排気を行うルーツポンプが 多く使われている ${ }^{3)}$. ロータ同士，打よび，ロータとケーシ ングとの間は微少な間隙（ $0.1 \sim 0.5 \mathrm{~mm}$ 程度）を保って回転 している。したがって，摺動に伴う潤滑油を必要とせず，高 真空側への油分子の逆流による污染の心配がない.

\subsubsection{3 ドライポンプ}

最近は，オイルフリーのドライポンプが多く使用されてい る. ドライポンプとは, 特定のポンプの形式ではなく, 半導 体産業・液晶産業や測定機器などの分野で油蒸気の逆流を嫌 って, 油回転ポンプに代わって用いられている, 油を用いな いポンプの総称である.JIS では「油又は液体を運動する部 分のすきをを密閉する目的に使用しない容積移送式真空ポン プ」と規定されている．上記のルーツポンプを多段にして，
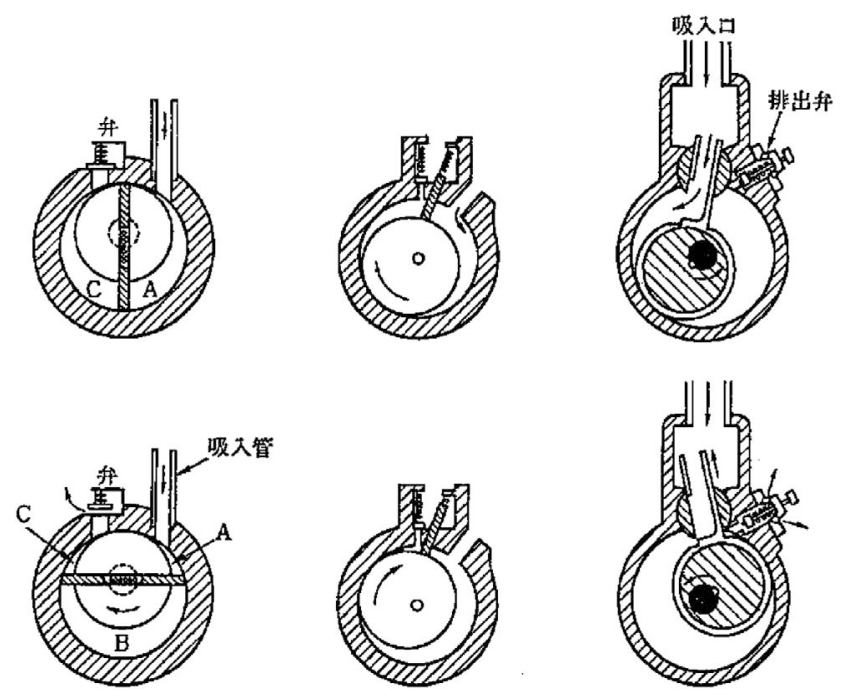

(a) 回枟侽型
大気圧から排気を可能にしたポンプの例を図12に示す4).ド ライポンプの問題点として，CVD やエッチングプロセスな ぞで使用すると，ポンプ内部に固形の中間生成物が出来て動 作を阻害することがある. これを避けるためにポンプの温度 コントロールを行い, 長時間安定して排気できるポンプも市 販されている.

その他の回転式のドライポンプとして, スクリュー真空ポ ンプ, クロー真空ポンプ, スクロール真空ポンプなどがある.

更に, 往復動式のドライポンプとして, ピストン真空ポン プ, ダイアフラム真空ポンプ, ベローズ真空ポンプなども使 用されている.

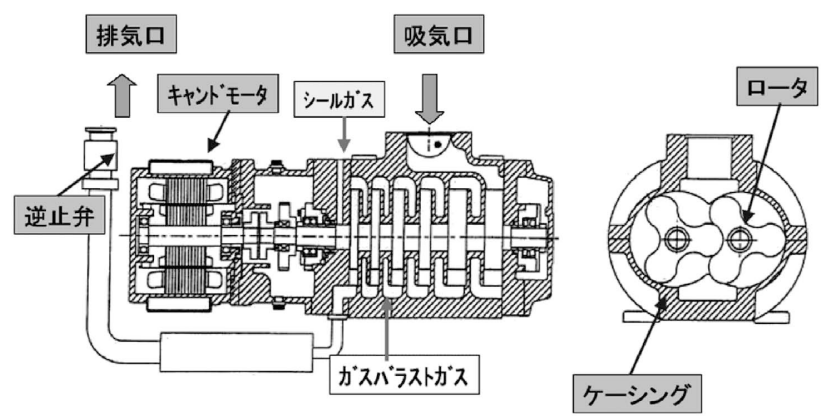

図12 多段ルーツ型のドライポンプの概略構造の例（株式会社 アルバックの許可を得て文献 4 より転載).

図10回転翼形油回転ポンプ(a), カム形油回転ポンプ(b), 摇動ピストン形油回転ポンプ(c)の排気動作（共立出版 株式会社の許可を得て文献 3 より転載).

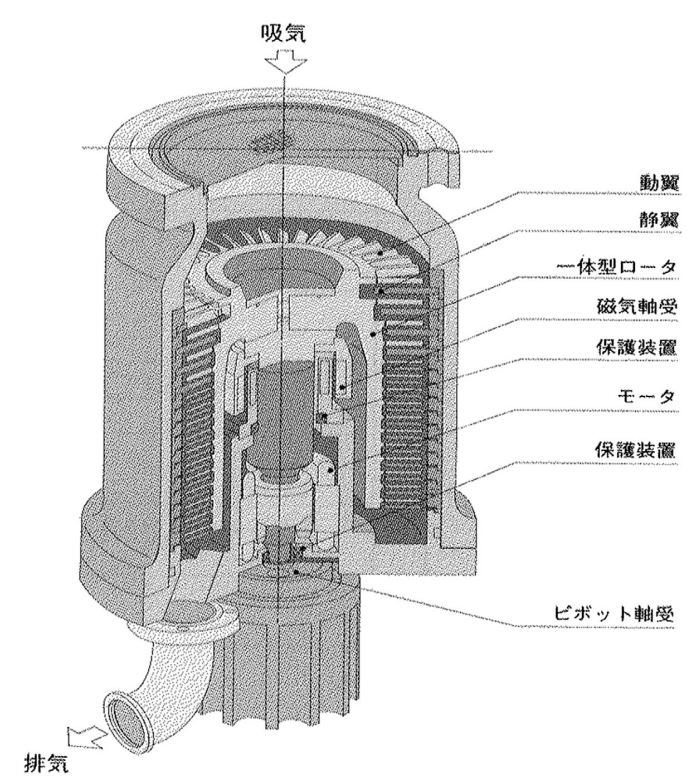

図13 ターボ分子ポンプの概略構造の例（株式会社アルバック の許可を得て文献 4 より転載).

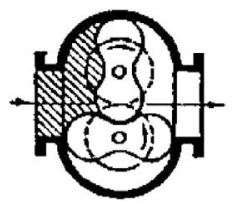

(a)

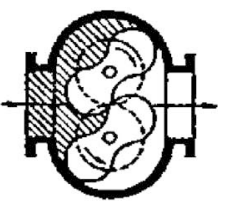

(b)

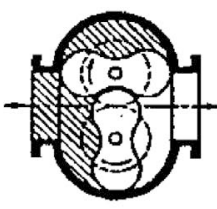

(c)

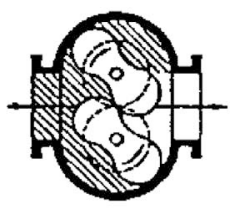

(d)

図11 ルーツ真空ポンプの排気動作（共立出版株式会社の許可を得て文献 3 より転載). 


\subsection{2 運動量輸送式真空ポンプ}

運動量輸送式真空ポンプの代表として, ターボ分子ポンプ を取り上げる．図13に市販されている機種の概略構造の一例 を示す ${ }^{4)}$. 排気速度としては, 約 $0.01 \mathrm{~m}^{3} \mathrm{~s}^{-1} \sim 6 \mathrm{~m}^{3} \mathrm{~s}^{-1}$ の機 種が市販されている. ターボ分子ポンプは, 分子流領域で働 く機械式ポンプである.

タービン翼を高速回転させ，その運動速度が気体分子の熱 運動の速度と同程度になると, タービン翼の傾きに応じて, 吸気側から排気側への気体分子の通過確率と排気側から吸気 側への通過確率の間に差ができる. その効果により, 排気を 行うのが動作原理である.

ターボ分子ポンプの長所は,

・気体ため込み式ポンプとちがい, 長時間の連続運転がで きる.

・重い分子ほど圧縮比が大きいので, 油潤滑が使用されて いても，正常に運転されていれば油蒸気分子の逆流によ る污染がない.

・クライオポンプなどに比べて起動時間が短い.

などである。

一方，欠点としては，

・ポンプ停止時には, ポンプを清浄な気体で満たしておく 必要がある。さもないと, 油分子の拡散による污染が発 生する。

・ポンプの構造上, 高温での脱ガスができないので, ポン プ自体が放出ガス源になることがある.

・水素のような軽い気体分子に対し圧縮比が小さい. などである。

最近では，油潤滑を使わない磁気軸受のポンプが多く使用 されている.

\section{2 気体ため込み式真空ポンプ}

気体ため込み式真空ポンプには，低温面への気体の物理吸 着を利用した, クライオポンプ, ソープションポンプなど と, 化学吸着を利用したゲッターポンプ, スパッタイオンポ ンプ，サブリメーションポンプなどがある，ここでは，代表 として, クライオポンプを紹介する.

クライオポンプでは，低温に冷却した面に，気体分子を凝 縮, 吸着させて排気を行う。通常の真空装置で使用されるク ライオポンプでは, 小型ヘリウム冷凍機で冷却が行われる5) (図14).

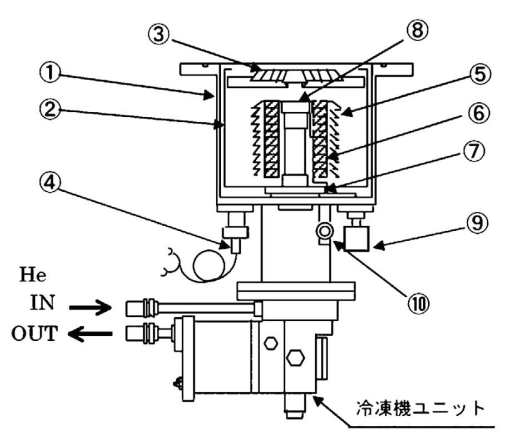

(1)ポンプケース

(2) $80 \mathrm{~K}$ シールド

(3) $80 \mathrm{~K}$ バッフル

(4) $\mathrm{K}(\mathrm{CA})$ 熱電対

(5) $15 \mathrm{~K}$ クライオパ 视(1)(凝絔パ补)

(6) $15 \mathrm{~K}$ クライオパ 视(2)(吸着パ 视)

(7)冷凍機 1 段ステージ

(8)冷凍機 2 段ステージ

(9)クラ仏熱電対温度計 MBS 型

(10)安全弁

図14 クライオポンプの概略構造の例（アルバック・クライオ 株式会社の許可を得て文献 5 より転載).

冷凍機の第 1 段のステージに取付けられるシールド，バ ッフルは, 約 $80 \mathrm{~K}$ まで冷却される.この部分では, 主とし て水分子が凝縮排気される. 約 $15 \mathrm{~K}$ まで冷却される第 2 段 のステージに取り付けられた凝縮パネルには, 窒素, 酸素, アルゴンなどが凝縮する。 $15 \mathrm{~K}$ ではまだ蒸気圧が高いへリ ウム, 水素, ネオンは, 吸着パネルに貼り付けられた吸着剤 で吸着排気される.

現在のところ, 小型冷凍機付クライオポンプは, 窒素の排 気速度にして $\quad 0.1 \mathrm{~m}^{3} \mathrm{~s}^{-1} \sim 30 \mathrm{~m}^{3} \mathrm{~s}^{-1}$ にわたる多くの機種が 市販されている. 圧力によるクライオポンプの排気速度の変 化を見ると， $10^{-2} \mathrm{~Pa} \sim 10^{-8} \mathrm{~Pa}$ 程度の圧力領域ではほぼ一 定であるが， $10^{-2} \mathrm{~Pa}$ 程度以上では，バッフル部分の流れが 分子流から粘性流へ変化するにつれ，コンダクタンスが大き くなり排気速度が上昇する． $10^{-1} \mathrm{~Pa}$ 程度以上になると, 排 気する気体による熱負荷が大きくなり, 排気速度が低下し, 不安定になる。通常は, クライオポンプは $10^{-1} \mathrm{~Pa}$ 程度以下 で使用する。ただし，スパッタ装置用クライオポンプとして 高圧力領域で安定して動作するよう工夫された機種もある.

クライオポンプは, ため込み式のポンプであるから, 一定 量の気体を排気（すなわち凝縮）した後は, それを追出す再 生操作が必要になる. 小型冷凍機付クライオポンプでは, 水 素やへリウムは吸着剤への吸着で排気されるので排気容量が 小さい. しかし, 自動的に再生操作を行うよう構成されたシ ステムとして使うことでこの欠点も克服される.

クライオポンプの特長は,

・同じ吸気口径の他のポンプに比べると, 排気速度が大き w.

・気体の排気処理量が大きい.

・ポンプ内の大部分の表面が低温であるため, ポンプ自身 からのガス放出量が小さい.

・油分子など重い分子は，低温での蒸気圧が十分低くなる ので, 油分子による真空容器の污染がない.

などである. クライオポンプを用いることで, 清浄な大型超 高真空を生成することができる.

\section{1.おわりに}

真空ポンプで真空容器を排気するときの圧力変化を表す 「排気の式」を解く方法を解説した．それに関連して，気体 の流量, コンダクタンス, 排気速度などの真空技術の基本的 項目も説明した。さらには, 真空ポンプの分類について述 べ，代表的なポンプの説明も行ったこのの「解説」での記述 は, 基礎的・概略的なものなので, 更に詳しく知るために は，参考文献に掲げた文献を学ぶ，日本真空学会が主催する 真空夏季大学に参加するなどをお勧めする.

\section{〔文献〕}

1）日本規格協会：真空技術一用語一JIS Z8126-2（1999）.

2）日本機械学会：機械工学便覧 B5 流体機械（丸善, 東京, 1986) p. 159.

3) 小宮宗治 : 実験物理学講座「真空技術」(共立出版, 東京, 1985) p. 196, 199.

4）侏アルバック：カタログおよびプレゼン資料.

5）アルバック・クライオ蛛：研修資料. 
さらに深く理解するためには下記文献が有用である.

A）真空夏季大学テキスト (第 32,33 抢よび 37 回).

B）熊谷寛夫, 富永五郎編著：真空の物理と応用（裳華房, 東京, 1970).

C) 富永五郎, 辻 泰訳：超高真空の物理（岩波書店, 東京, 1968).

D）八田吉典：気体放電（東北大学基礎電子工学入門講座，近代科 学社, 東京, 1968).
E）林 主税編集：真空技術（共立出版，東京，1985）.

F）堀越源一：真空技術（第 3 版）（東京大学出版会, 東京, 1994）。

G）石川和男訳：真空技術とその物理（丸善，東京，1995）.

H）山科俊郎, 広畑優子 : 真空工学（共立出版, 東京, 1991).

I）日本真空協会関西支部編：わかりやすい真空技術（日刊工業新 聞，東京，1990）。

J）日本機械学会編：機械工学便覧A5（丸善，東京，1987）.

K）日本機械学会編：原子・分子の流れ（共立出版, 東京, 1996). 